\title{
Abundance and exploitation of loggerhead turtles nesting in Boa Vista island, Cape Verde: the only substantial rookery in the eastern Atlantic
}

\author{
A. Marco ${ }^{1}$, E. Abella ${ }^{1,2}$, A. Liria-Loza ${ }^{3}$, S. Martins², O. López ${ }^{3}$, S. Jiménez-Bordón³, M. Medina ${ }^{3}$, \\ C. Oujo ${ }^{3}$, P. Gaona ${ }^{1}$, B. J. Godley ${ }^{4}$ \& L. F. López-Jurado ${ }^{2,3}$ \\ 1 Estación Biológica de Doñana, CSIC, Seville, Spain \\ 2 Cabo Verde Natura 2000, Sal Rei, Boa Vista, Cape Verde \\ 3 Instituto Canario de Ciencias Marinas, ICCM, Gran Canaria, Spain \\ 4 Centre for Ecology \& Conservation, University of Exeter, Penryn, Cornwall, UK
}

\section{Keywords}

Africa; threats; marine turtles; loggerheads; nesting population; Cape Verde; monitoring.

\section{Correspondence}

Adolfo Marco, Department for Biodiversity Conservation, Estación Biológica de Doñana, CSIC, Americo Vespucio s/n, Sevilla 41092, Spain.

Email: amarco@ebd.csic.es

\begin{abstract}
The main nesting area for loggerhead turtles in the eastern Atlantic is in the Cape Verde Islands, largely restricted to the island of Boa Vista. Extensive monitoring demonstrated a globally significant population for the species despite a sustained high level of anthropogenic take of nesting females for local consumption. Through an extensive stratified monitoring program across the island in the seasons 2007-2009, we estimated a total of 13 955, 12028 and 19950 clutches in the 3 years, respectively. These values indicate that the mean number of nesting females averaged 3700. Considering that a female breed, on average, every 2.4 years, we estimate that the overall number of adult females in the population during these three seasons was 8900 . These levels are much higher than those suggested in previous studies which were more constrained in spatial coverage. Our findings indicate that Cape Verde hosts the third largest nesting aggregation for this species in the world after the south-eastern US and Oman, with some sites having a particularly high density of nests, facilitating targeted monitoring and conservation. Consumption of sea turtle meat is a traditional practice in Cape Verde that continues despite national sea turtle protection laws. We estimated that 36,18 and $5 \%$ of nesting females were harvested in the 3 years of the study, respectively. Increasing beach protection and monitoring, ongoing educational programs and cooperative projects with local communities are urgently needed to further safeguard the only major loggerhead nesting aggregation in the eastern Atlantic.
\end{abstract}

\section{Introduction}

Deriving reliable indices of population abundance and obtaining an appreciation of key habitat use have become increasingly important for marine megavertebrate species that face a range of threats (Ausubel, 1999; Halpin et al., 2006; Bearzi, 2007; Godley \& Wilson, 2008; Robertson, 2008). Estimating population trends for species that are widely dispersed, sometimes at the scales of whole ocean basins, is complicated and resource intensive (Forney, 2000; Taylor et al., 2007; Hammond, 2010), but can be facilitated when species exhibit predictable migrations to form seasonal breeding aggregations (Poncet et al., 2006; Stevick et al., 2006; Ramos et al., 2009; Foote et al., 2010). This is the case for marine turtles, where nonbreeding adults disperse at scales that range from regional to whole ocean basins (Godley et al., 2008). Breeding adults aggregate seasonally at a discrete number of rookeries, allowing numbers of nests to be used as an index of population size (Eckert et al., 1999).

The loggerhead turtle (Caretta caretta) is distributed circumglobally and although being locally abundant at key sites is considered endangered (IUCN, 2011). Work since the 1970s established that the major nesting sites in the Atlantic were the south-eastern US (Witherington et al., 2009), the Mediterranean (Margaritoulis et al., 2003) and Brazil (Marcovaldi et al., 2007). In recent years, however, it has become clear that significant numbers of loggerheads also nest in the Cape Verde Islands (Schleich, 1979; LópezJurado et al., 2000a). Extensive surveys in the eastern Atlantic suggested that this insular rookery is currently the only significant nesting aggregation between South Africa and western Europe (Fretey, 2001; Ehrhart, Bagley \& Redfoot, 2003; Barnett et al., 2004; Weir et al., 2007; Catry et al., 2009; Tomas et al., 2010). 
Although juveniles disperse at the scale of ocean basins, turtles can be found in mixed stocks on their foraging grounds (Bolten et al., 1998; Monzón-Argüello et al., 2009, 2010c). As adults they exhibit high levels of natal philopatry (Bowen et al., 1994; Carreras et al., 2007; Reis et al., 2010; Monzón-Argüello et al., 2010c). Thus, several genetic stocks have been identified in the Atlantic, based on mitochondrial and nuclear DNA (Encalada et al., 1998; Carreras et al., 2007). Such work has revealed significant differences between Cape Verde and all previously sequenced Atlantic and Mediterranean rookeries (Monzón-Argüello et al. 2010c). For this reason, the Cape Verde population constitutes a key conservation unit that deserves specific monitoring efforts and conservation measures.

Historic information suggests that nesting loggerheads were extremely abundant throughout Cape Verde in centuries past (review in López-Jurado, 2007; Loureiro \& FerrazTorrao, 2008). Substantial catches of adult females for human consumption have been documented and are thought to have led to substantial reductions of nesting levels on the most populous islands (López-Jurado, 2007). Qualitative surveys conducted during the last decade indicated that the relatively sparsely populated island of Boa Vista was the last stronghold of nesting, while breeding levels on the rest of the islands were significantly lower (López-Jurado et al., 2000a). Detailed nesting surveys of a limited number of beaches of south-eastern Boa Vista, conducted between 2001 and 2006, recorded up to 5400 clutches per annum (López-Jurado, Sanz \& Abella, 2007; VaroCruz, Cejudo \& López-Jurado, 2007), confirming the global importance of the island. Slaughter of adult females was also highlighted as an important threat (Cabrera et al., 2000; López-Jurado et al., 2000b; López-Jurado, Varo-Cruz \& López-Suárez, 2003).

Despite the clear importance of the Cape Verde nesting population, the majority of the coastline of Boa Vista had not been surveyed for loggerhead nests and the level of exploitation was unknown. There was a clear need to extend survey work to: (1) allow the first full appraisal of the relative importance of the rookery; (2) set a baseline for the long-term monitoring of this rookery; (3) determine the areas of higher nest density so that they can be protected for turtle nesting; and (4) evaluate the spatial distribution and magnitude of key threats. These data would facilitate power to detect trends as well as facilitate the targeting of conservation action. Here we present the results of the first extensive monitoring throughout the island of Boa Vista for nesting and illegal take conducted during three consecutive years. We discuss lessons learned and highlight priorities for future work.

\section{Methods}

\section{Study area}

This study was carried out in the island of Boa Vista, Republic of Cape Verde $\left(16^{\circ} 02^{\prime} \mathrm{N}, 2^{\circ} 45^{\prime} \mathrm{W}\right.$; Fig. 1a,b). The coastline varies from urban to near-wilderness states. White sandy beaches are found around most of the island with high-energy shores, open to the sea, without visible obstacles in the sea (islands or reefs). Some factors strongly varied among and within sites such as slope, width and abundance of clay, vegetation and stones. All sandy beaches were surveyed by foot, mapped and geo-referenced using GPS (Garmin e-trex summit). Despite the logistical difficulty in surveying some parts of the island, no beach longer than $50 \mathrm{~m}$ was excluded from the surveying regime. We divided the coastline into 10 survey zones of different lengths that spanned stretches between major natural landmarks (S1S10; Fig. 1; Table 1).

\section{Nesting activity survey}

We based our monitoring strategy upon that previously used for green turtles at Ascension Island (Godley, Broderick \& Hays, 2001). We had a stratified monitoring protocol whereby several beaches with previously known high nesting density were surveyed almost daily during three nesting seasons (2007-2009; 15 June to 10 October) and others were monitored more intermittently (Table 1; Fig. 1). The intensive survey sites (S7 and S8 in 2007-2009; S4-S8 in 2009) included two known high-density nesting beaches in S8 chosen as reference or index sites (Ervatao and Ponta

Table 1 Distribution of beaches among 10 sections and their length and orientation

\begin{tabular}{cllcc}
\hline ID & Location & Main beaches & Length $(\mathrm{km})$ & Orientation \\
\hline 1 & P. Morro de areia - P do Sol & Chaves, Cabral & 12.15 & $\mathrm{~W}$ \\
2 & P do Sol - Ponta Seringa & Boa Esperanza & 3.40 & $\mathrm{~N}$ \\
3 & P. Seringa - P. Velho Branco & Lancha, Gatas & 5.20 & $\mathrm{~N}$ \\
4 & P. Velho Branco - P. do Rife & Canto, Simon Nho Narda & 4.15 & $\mathrm{NE}$ \\
5 & P. do Rife - P. C. Tartaruga & Figura, Flor, Nho Martin & 4.55 & $\mathrm{E}$ \\
6 & P. C. tartaruga - P. do Roque & Carreto, Praiona & 1.55 & $\mathrm{E}$ \\
7 & P. do Roque - P Ervatao & Laiedo Teixeira, Caletha & 2.50 & $\mathrm{SE}$ \\
8 RB & P. Ervatao - P. Medronho & Ervatao, P. Cosme, Barrosa & 7.80 & SE \\
9 & P. Medronho - I.Curral Velho & Curral Velho & 4.75 & SW \\
10 & I. Curral Velho - P. Morro Areia & Lacacao, Sta. Monica & 21.60 & S-SW \\
& Island of Boa Vista (total) & & 67.65 & \\
\hline
\end{tabular}

P, Ponta; I, Ilheu; RB, reference beaches for interpolation. 

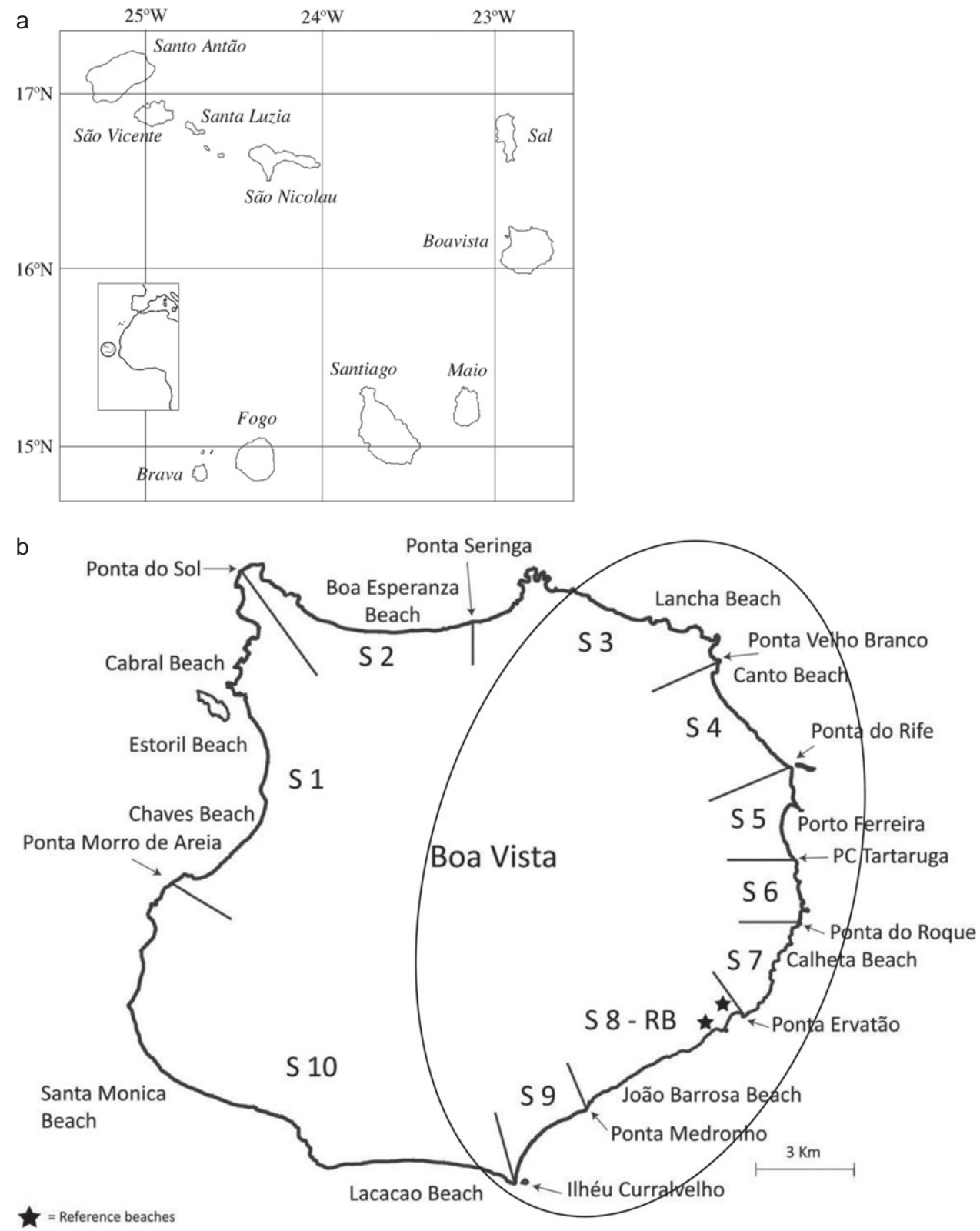

Figure 1 (a) Map of Republic of Cabo Verde, western Africa. The location of the archipelago. (b) Detail of Boa Vista with indication of coastal sections (S1-10), their limits and the reference beaches $(\mathrm{Y})$. The ellipse includes the two protected areas that hold more than $80 \%$ of nesting.

Cosme; 3 km; Fig. 1b, Table 2). These were surveyed daily throughout the three seasons to determine the seasonal nesting pattern (Fig. 2). During the night, females emerge onto the beach for nesting. However many nesting activities do not result in egg deposition, with females abandoning prior to oviposition. During this process, females leave tracks in the sand that can allow observers to assess whether egg laying has resulted. Tracks were enumerated and assessed during early morning surveys (Schroeder \& Murphy, 1999) and erased following counting. To estimate nesting success of each beach, we divided the number of successful activities by the total number of activities.
Because a small proportion (never more than 3\%) of the tracks of nesting activities could not be definitively categorized as having resulted in successful clutch deposition, for each count a maximum and a minimum number of nests were assigned. When logistical difficulties occasionally precluded surveys, nests from two nights previous could still be discerned. There were, however, periods when surveying was absent for multiple days (maximum duration 4 days). In this case, missing counts were estimated by interpolation of mean values of daily counts using data from the 5 days before and 5 days after the data gap. Days with missing counts were never constituted more than $20 \%$ of nesting 
Table 2 Minimum number, percentage and density (nests $\mathrm{km}^{-1}$ ) of loggerhead nests laid on all beaches (10 sections and 2 reference beaches) of Boa Vista (Cape Verde) during the nesting seasons of 2007, 2008 and 2009

\begin{tabular}{|c|c|c|c|c|c|c|c|c|c|}
\hline \multirow{2}{*}{$\begin{array}{l}\text { Nests } \\
\text { Sections }\end{array}$} & \multicolumn{3}{|l|}{2007} & \multicolumn{3}{|l|}{2008} & \multicolumn{3}{|l|}{2009} \\
\hline & Num & $\%$ BV & $\mathrm{N} \mathrm{km}^{-1}$ & Num & $\%$ BV & $\mathrm{N} \mathrm{km}^{-1}$ & Num & $\%$ BV & $\mathrm{N} \mathrm{km}^{-1}$ \\
\hline S1 & 54 & 0.4 & 4.4 & 94 & 0.8 & 7.7 & 32 & 0.2 & 2.6 \\
\hline S2 & 265 & 2.0 & 77.9 & 492 & 4.1 & 144.7 & 440 & 2.2 & 129.4 \\
\hline S3 & 364 & 2.6 & 70.0 & 306 & 2.5 & 58.8 & 413 & 2.0 & 79.4 \\
\hline S4 & 669 & 4.8 & 161.2 & 336 & 2.8 & 81.0 & $1024^{a}$ & 5.1 & 246.7 \\
\hline S5 & 1087 & 7.8 & 238.9 & 761 & 6.3 & 167.3 & $1688^{a}$ & 8.4 & 371.0 \\
\hline S6 & 682 & 4.9 & 440.0 & 532 & 4.4 & 343.2 & $1022^{\mathrm{a}}$ & 5.1 & 659.4 \\
\hline $\mathrm{S} 7+\mathrm{S} 8$ & $8903^{a}$ & 63.8 & 864.4 & $7599^{a}$ & 63.2 & 737.8 & $12640^{a}$ & 62.9 & 1227.2 \\
\hline RB Ervatao & 1239 & 8.9 & & 1111 & 9.2 & & 1669 & 8.3 & \\
\hline RB Ponta Cosme & 1961 & 14.0 & & 1402 & 11.7 & & 2506 & 12.5 & \\
\hline s9 & 1204 & 8.6 & 253.5 & 633 & 5.3 & 133.3 & 1159 & 5.8 & 244.0 \\
\hline S10 & 727 & 5.2 & 33.7 & 1275 & 10.6 & 59.0 & 1684 & 8.4 & 78.0 \\
\hline Boa Vista & & 13955 & & & 12028 & & & 20102 & \\
\hline
\end{tabular}

${ }^{a}$ More than $80 \%$ of these nests were counted on the beach and the rest were estimated from periodic counts; nests in the reference beaches (RB) are also included in sections 7 and 8; approximate confidence intervals: S1 = 20\%; S2-S3 = 5\%; S4, S5, S6, S9, S10 = 3\%; S7-S8<3\%.

days and at the reference beaches these made up less than $10 \%$ of days.

All additional beaches (Table 1) were periodically surveyed on at least four occasions during 2007 and 2008, and on at least six occasions during 2009. This involved visits on two successive days. On day 1 , we enumerated and marked all nests since the previous count, and early the next morning we recorded all nesting in the intervening night. For extrapolations, we only used the counts from the previous nesting night. An estimate of the overall number of turtle nests on these beaches was generated by extrapolation using the nest counts in two selected reference or index beaches from section 8 (Fig. 2). For the extrapolation, the beaches with periodical counts were grouped into sections (2007 and 2008: 1-6, 9 and 10; 2009: 1-3, 9 and 10) that were characterized by having more than $10 \mathrm{~km}$ length or alternatively more than 200 nests during the season. The beaches from each grouping were monitored on the same days. For the extrapolations, a scaling factor was created for each morning count of nests of an entire section by dividing it by the 11days running mean of nesting on the reference beaches centered upon the same day (Fig. 2). This scaling factor was used to estimate the total number of nests for the beach sector for a time period before and after the count. These time periods were from the preceding midpoint of the intersurvey interval until the midpoint of the subsequent intersurvey interval. The exceptions were the first count which effectively spanned the period from the beginning of the season to the midpoint of the first inter-survey interval and the last count which covered from the midpoint of the final inter-survey interval until the end of the season. The total number of nests on the reference beaches during any time interval was multiplied by the relevant scaling factor, thus estimating the number on nests laid on each beach section during the given time interval. These overall estimated values were compared with the total number of nests counted on each beach section during the periodic surveys. The error of the extrapolations was estimated multiple times

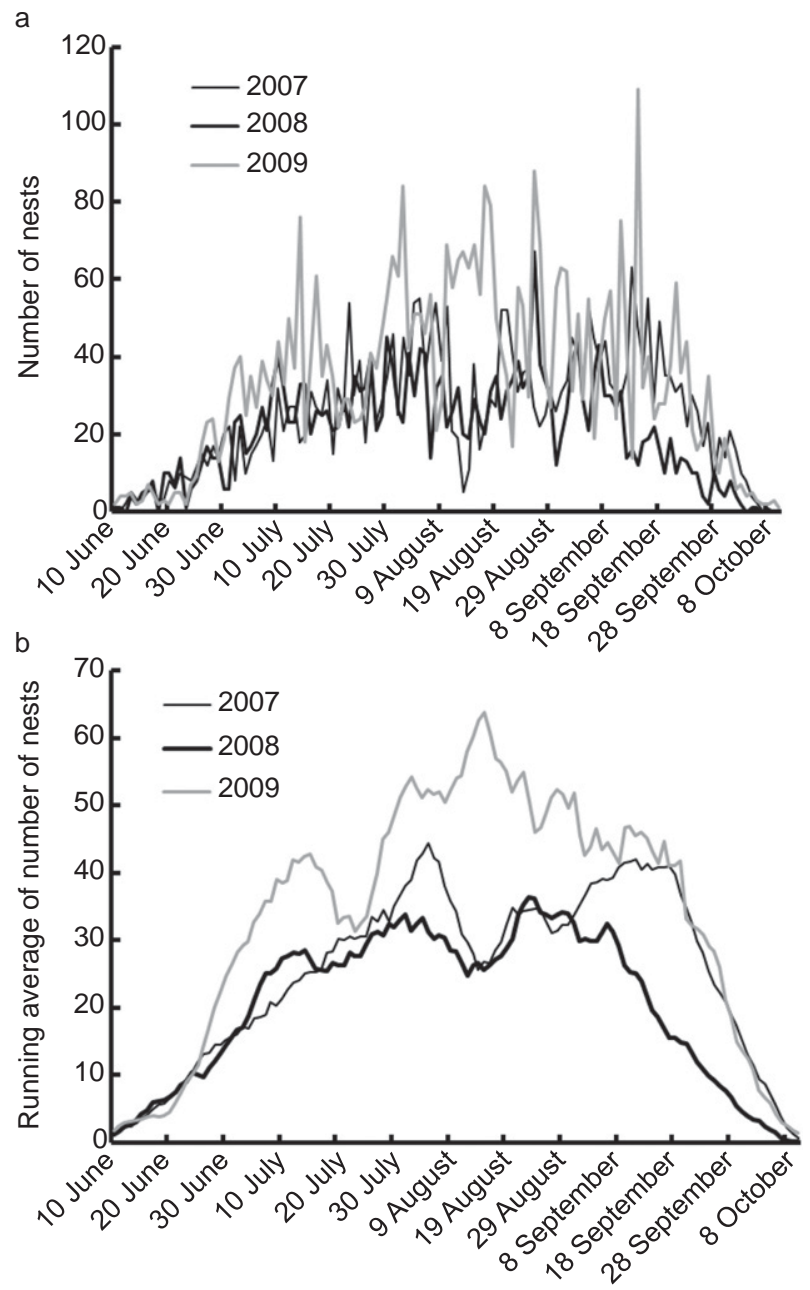

Figure 2 The temporal pattern of the number of nests (a) and of combined nesting (b) at reference beaches on section 8 in the three nesting seasons 2007-2009. 
using data from beaches, other than references beaches, with daily surveys and was typically less than $5 \%$.

The total number of nesting females on protected beaches with very low mortality rate (S7-S8) was calculated by dividing the total number of nests laid in that season by the estimated mean number of nests laid by each female during a given season in Boa Vista (3-5; Varo-Cruz et al., 2007). On beaches with significant female mortality, the number of nests decreased throughout the season. For that reason, on these beaches (S1-S6 and S9-S10) we estimated the number of nesting females during the second half of July, when the vast majority of females are already nesting. To do that, we added the daily number of nests laid during 14 consecutive days because 15 days is the mean inter-clutch interval (VaroCruz et al., 2007). To this value, we added the number of females killed on that beach before the end of July, assuming that most of females are killed before they lay their eggs.

\section{Surveys of adult take}

During all nest counts, the observers also followed and recorded all the female tracks that did not appear to return to the sea. In some cases, females were trapped on rocks, lost on land or turned on their carapaces. If they were alive, they were helped to return to the water. In most cases, however, we discovered evidence that turtles had been butchered on the beach or surrounding areas and carcasses were abandoned nearby. In some cases where the females were not found, the observers were able to assign anthropogenic take from the signs of turtles being dragged along beaches until they were loaded into vehicles, boats and onto donkeys. If they were dead, the observers examined the carcasses to help distinguish whether they had been killed by humans or they died of natural causes. Live females that were rescued by observers, including those that had been left upside down for later collection, were not considered as hunted females. To calculate the proportion of females taken for each nesting season, we divided the number of hunted females by the estimated number of nesting females.

\section{Results}

The start and end of nesting were very similar across the three study years, although the seasonal pattern of nesting showed some variation (Fig. 2). Nesting was recorded in early June until the middle of October (Fig. 2). The peak of nesting was in August in the three seasons, with a highly similar central $90 \%$ around the median nest in both study years. The vast majority of nesting occurs between June 15/18 and October 5/8.

In total, we directly observed 32784 nesting activities in 2007, 21532 nesting activities in 2008 and 61609 nesting activities in 2009. The nesting success was relatively low, although it varied among sites and years from 25\% for 2009 to $39 \%$ for 2008 . We counted a total of 10588 successful nests for 2007, 8382 for 2008 and 15407 for 2009. These values do not include the tracks for which definitive nesting could not be assigned.
Table 3 Minimum number of loggerhead females taken on the beaches of the island of Boa Vista (Cape Verde) during the nesting seasons of 2007, 2008 and 2009

\begin{tabular}{|c|c|c|c|c|c|c|}
\hline \multirow{2}{*}{$\begin{array}{l}\text { Hunted turtles } \\
\text { Sections }\end{array}$} & \multicolumn{2}{|l|}{2007} & \multicolumn{2}{|l|}{2008} & \multicolumn{2}{|l|}{2009} \\
\hline & Number & $\%$ & Number & $\%$ & Number & $\%$ \\
\hline S1 & 5 & 0.4 & 1 & 0.3 & 0 & 0.0 \\
\hline S2 & 178 & 14.2 & 30 & 7.3 & 79 & 36.7 \\
\hline S3 & 134 & 10.7 & 77 & 18.9 & 7 & 3.3 \\
\hline S4 & 245 & 19.5 & 55 & 13.5 & 22 & 10.2 \\
\hline S5 & 337 & 26.9 & 40 & 9.8 & 4 & 1.9 \\
\hline S6 & 90 & 7.2 & 72 & 17.6 & 26 & 12.1 \\
\hline $\mathrm{S} 7+\mathrm{S} 8$ & 8 & 0.6 & 20 & 4.9 & 12 & 5.6 \\
\hline S9 & 130 & 10.4 & 53 & 13.0 & 11 & 5.1 \\
\hline S10 & 126 & 10.1 & 60 & 14.7 & 54 & 25.1 \\
\hline Boa Vista & 1253 & & 408 & & 215 & \\
\hline
\end{tabular}

The validation of the extrapolation and interpolation methods on beaches with daily surveys other than the reference beaches indicated a high accuracy of estimations. The difference between the total number of nests daily counted on the beach and the number of nests estimated using data from daily nest counts of 4 or 6 isolated days scattered during the nesting season was lower than $4 \%$ for beaches with more than five nests per day. For beaches with less than five daily nests, the accuracy of the estimation of the total number of nests decrease (up to $20 \%$ of difference between direct counts and estimations), but the contribution of these beaches to the total number of nests on the island was very small. Using the interpolation and the extrapolation methods for all beaches, the estimations of the total number of nests laid in Boa Vista were 13 955, 12028 and 20102 for 2007, 2008 and 2009, respectively (Table 2). During the study years, the estimated number of adult females in the island ranged from 2791 to 4652 in 2007, from 2406 to 4009 in 2008 and from 4020 to 6701 in 2009. Considering that females nest on average every 2.4 nesting seasons (VaroCruz et al., 2007), we calculated a mean total number of adult females in the population of $8900(S D=2400$, CI $95 \%=2700$ ).

The distribution of nesting is not homogeneous around the island. Approximately $90 \%$ of nests are found on the beaches of the eastern half of the island (Reserva Natural de Tartarugas and Parque Natural del Norte). We have identified a very important coastal stretch totaling $10 \mathrm{~km}$ in the south-eastern of Boa Vista that holds $60-65 \%$ of nesting activity (Reserva Natural de Tartarugas; Table 2). Nest density can be very high in some beaches, with records of up to 2.0 nests per meter at the end of the nesting season on several beach sections longer than $800 \mathrm{~m}$. Ervatao beach (section $8=0.8 \mathrm{~km}$ ) had the highest density for loggerhead nest in the study area during 2009 (2100 nests $\mathrm{km}^{-1}$ ).

In 2007, more than 1200 females, around $40 \%$ of the total number of females that nested on the Island that year, were killed on unprotected beaches (Table 3). These counts likely underestimated the problem because of the difficulty of the detection of evidence of hunting of females captured at remote sites and transported elsewhere for butchering as 
Table 4 Summary of published data about the magnitude of nesting at major loggerhead turtle rookeries across the world

\begin{tabular}{llrl}
\hline Ocean & Location & Annual nests & References \\
\hline Atlantic & SE United States of America & 58429 & \\
& Florida (USA) & 52469 & $\begin{array}{l}\text { Florida Fish and Wildlife Conservation Commission, Fish and Wildlife Research } \\
\text { Institute, Marine Turtle Program, 2011 }\end{array}$ \\
& South Carolina (USA) & 4078 & Griffin \& South Carolina Department of Natural Resources, 2007 \\
& Georgia (USA) & 1199 & Dodd \& Mackinnon, 2005 \\
& North Carolina (USA) & 647 & Godfrey \& North Carolina Wildlife Resources Commission, 2007 \\
& Cape Verde (previous data) & 5400 & López-Jurado et al., 2007 \\
Cape Verde & 15300 & Present study \\
& Brazil & 5285 & Marcovaldi et al., 2007 \\
& Greece & 3472 & Casale \& Margaritoulis, 2010 \\
& Turkey & 2145 & Casale \& Margaritoulis, 2010 \\
& Mexico & 961 & FFC México, 2006 \\
& Libya & 841 & Casale \& Margaritoulis, 2010 \\
& Cyprus & 694 & Casale \& Margaritoulis, 2010 \\
& Oman (Masirah island) & 30000 & Baldwin et al., 2003 \\
Indo-Pacific & 5167 & Kamezaki et al., 2003 \\
& Japón & 1728 & Nel, Wright \& KwaZulu-Natal, 2007 \\
& South Africa & 800 & Mau et al, 2007 \\
\hline
\end{tabular}

Most of the values correspond to censuses conducted after 2000. Data from the present study are included.

well as those that may be captured at sea. The mortality rate was substantially lower in 2008 (18\% of nesting females) and lower still in 2009 (5\% of nesting females; Table 3).

\section{Discussion}

The available information for the entire eastern Atlantic highlights that Cape Verde is clearly a hot spot for the distribution and conservation of the loggerhead turtle (Fretey, 2001; Weir et al., 2007). The entire Archipelago hosts more than $95 \%$ of loggerhead nesting on the entire eastern Atlantic (Fretey, 2001). Between 80 and $85 \%$ of all nests are laid on just $40 \mathrm{~km}$ of beaches of the eastern half of Boa Vista.

Previous extensive sea turtle nesting observations indicated that the loggerhead is the only species that nest in Boa Vista. The present study confirms this, although green and hawksbill juveniles are very often found feeding in their coasts (Monzón-Argüello et al., 2010a,b). This island is one of the less populated and has relatively inaccessible beaches, with all villages being relatively distant from the main nesting areas. Information gathered in other islands indicates that nesting there constitutes some $10 \%$ of Cape Verde's nesting effort. This includes nesting on the islands of Sal, Maio and San Nicolau, with nesting on the rest of the islands being very occasional (Schleich, 1979; López-Jurado et al., 2000a; Loureiro, 2008; Cozens et al., 2009).

Previous estimates of the number of nesting females using beaches in the study region were significantly lower (LópezJurado et al., 2007). Our data demonstrate that the nesting population in Cape Verde is of a considerably greater size, with an estimated 12 000-20000 nests annually and based on three to five nests per individual (Varo-Cruz, 2010) of the order of 2400-6700 nesting females per year. Moreover, some beaches from the south-east part of the Boa Vista demonstrate the highest density of nesting (> 1000 nest$\mathrm{s} \mathrm{km}^{-1}$ ) ever reported for the species. An overview of available studies suggests a global nesting effort of 130000 nests per year (Table 4). Thus, Cape Verde currently holds between 9 and 15\% of the world's loggerhead nesting and 13 and $22 \%$ for the Atlantic.

Decades of investigations of marine turtles have generated a great deal of knowledge of the status of this species in the western Atlantic and the Mediterranean (Broderick et al., 2002; Wallace et al., 2010). Until recently, however, for the eastern Atlantic we only had sporadic and isolated observations of loggerhead nesting along the coast of West Africa (Fretey, 2001). Therefore, the discovery of this important loggerhead turtle nesting site in Cape Verde fills a significant gap in known distribution of a species of high conservation interest.

Despite recent national sea turtle protection laws, the slaughter of nesting females on the beaches is still intense and threatens the survival of the population. During the past decades, female hunting together with the incidental catch of turtles in fisheries (López-Jurado et al., 2003) has almost extirpated loggerhead nesting from several islands of Cape Verde and hunters from other islands are now believed to be targeting Boa Vista.

During the past decade, several initiatives involving local groups have begun the implementation of conservation and educational programs seeking to change the attitudes and behaviors of the local population regarding turtles and their consumption (Espírito-Santo et al., 2008). Since 1998, the nongovernmental organization (NGO) Cabo Verde Natura 2000 , in collaboration with local institutions and social collectives, has monitored and protected this loggerhead population in the high-nesting density area (60-65\% of nests) of the Archipelago from the International Volunteer Sea Turtle Conservation Camp of Ervatão (S7 and S8). At the 
beginning of these conservation actions, the slaughter of females was very intense on these high-density beaches. During the 3 years of this study, these beaches only accounted for $6 \%$ of the females hunted in the island. Nocturnal patrols along these nesting beaches during the nesting season have apparently been an effective deterrent. In 2008, the NGO Turtle Foundation started the protection of several beaches in the eastern part of the island (S4 and S5), decreasing significantly the hunting pressure at these sites. In 2009, this NGO has extended their protection efforts to some important beaches in the north (S2 and S3) and west (S9) of the island. In 2009, Cabo Verde Natura 2000 established a new sea turtle conservation camp in Porto Ferreira beach, starting the protection of the second largest nesting area in the island (S4, S5 and S6). Between them, these two NGOs are now engaged in active protection on beaches that constitute more than $90 \%$ of loggerhead nesting in the island. But despite these efforts, determined turtle hunters continue to take turtles. The isolation and relative inaccessibility of some important beaches make patrolling and enforcement difficult. Of special concern is the concentration of potential hunters around new hotel constructions. Given the site's importance, there is a need to involve the community more deeply in the fate of the turtles nesting there. The Cape Verdean Government has recently approved regulations that prohibit the capture of marine turtles and the consumption or commercialization of any of its parts as well as the destruction or alteration of nesting habitats. Core nesting areas should be preserved from planned urbanization, with artificial lighting of nesting beaches and access by off-road vehicles being prohibited.

Boa Vista is one of the least populated islands of Cape Verde and most villages are located far from the coast. Moreover, access to the main nesting beaches is challenging as a result of topography and the general lack of roads. We suggest that these are likely the main reasons that explain why Boa Vista still hosts high levels of loggerhead nesting activity. In other more populated islands of Cape Verde, with more accessible beaches, the hunting pressure on female turtles has resulted in severe decline/near extirpation. Nesting on Boa Vista is clearly a key for the conservation of marine turtles in Cape Verde and the wider eastern Atlantic. The abundance of nests in Boa Vista together with relatively low hatching success (Abella et al., 2007; Varo-Cruz et al., 2007) offers the opportunity of translocation of doomed nests to other islands for restoration purposes. Before any translocation program, however, the protection of females, nests and hatchlings on the selected recipient beaches and the solution of proximate impacts that have necessitated restoration should be guaranteed.

Especially important for turtle protection are the coastal areas included in the Northern Natural Park and the Natural Reserve of Tartaruga. These two protected areas (Sections 3 to 9) include more than $85 \%$ of loggerhead nesting every season. The combination of the legal protection, the increasing awareness of the local inhabitants, international support of conservation programs, protection provided by NGOs and volunteers, and the demonstration of the economic income of alternative activities such as regulated ecotourism, will provide excellent conditions for conservation and maintenance of the species in the island. The conservation efforts should also be extended to the important foraging areas for green and hawksbill turtles in the same areas (Monzón-Argüello et al., 2010a,b).

In summary, our observations elevate the global importance of Cape Verde for loggerhead turtle conservation, suggesting that it is the third largest nesting aggregation globally, after the southeast coast of US and Oman (Baldwin, Hughes \& Prince, 2003; Ehrhart et al., 2003). This population is highly isolated from the continent as well as from other loggerhead nesting populations, and is subject to a range of threats. Educational programs and community participation should be reinforced in order to minimize the slaughter of turtles on the beaches. Ecotourism and responsible turtle watching should be regulated and considered as a potential sustainable alternative to the exploitation of turtle meat in the islands. We reiterate the need to have a long-term broader, more integrated population assessment in this population.

\section{Acknowledgments}

We would like to thank the many volunteers that visited the international turtle camps of Ervatao and Porto Ferreira for their help in collecting data. In addition, we appreciate the people from Boa Vista who accepted our visit and facilitated the monitoring activities. We also thank the local authority of Boa Vista and the national environmental authority of Cape Verde. Support came from the Gobierno de Canarias (Spain), the Junta de Andalucía (Spain), the European Union, the MTCF of NOAA (U.S.A.) and Fundación BBVA. B.J.G. was supported by the Darwin Initiative.

\section{References}

Abella, E., Marco, A. \& López-Jurado, L.F. (2007). Success of delayed translocation of loggerhead turtle nests: implications in management programs. J. Wildl. Manage. 71, 2290-2296.

Ausubel, J.H. (1999). Toward a census of marine life (guest editorial). Oceanography 12, 4-5.

Baldwin, R., Hughes, G.R. \& Prince, R.I.T. (2003). Loggerhead turtles in the Indian Ocean. In Loggerhead sea turtles: 218-232. Bolten, A.B. \& Witherington, B.E. (Eds). Washington: Smithsonian Books.

Barnett, L.K., Emms, C., Jallow, A., Cham, A.M. \& Mortimer, J.A. (2004). The distribution and conservation status of marine turtles in the Gambia, West Africa: a first assessment. Oryx 38, 203-208.

Bearzi, G. (2007). Marine conservation on paper. Conserv. Biol. 21, 1-3.

Bolten, A.B., Bjorndal, K.A., Martins, H.R., Dellinger, T., Biscoitom, M.J., Encalada, S.E. \& Bowen, B.W. (1998). Transatlantic developmental migrations of loggerhead sea turtles demonstrated by mtDNA sequence analysis. Ecol. Appl. 8, 1-7. 
Bowen, B.W., Kamezaki, N., Limpus, C.J., Hughes, G.R., Meylan, A.B. \& Avise, J.C. (1994). Global phylogeography of the loggerhead turtle (Caretta caretta) as indicated by mitochondrial-DNA haplotypes. Evolution 48, 18201828.

Broderick, A.C., Glen, F., Godley, B.J. \& Hays, G.C. (2002). Estimating the number of green and loggerhead turtles nesting annually in the Mediterranean. Oryx 36, 227-235.

Cabrera, I., Cejudo, D. \& López-Jurado, L.F. (2000). Human predation on marine turtles in the Archipelago of Cape Verde, Western Africa. In Proceedings of the nineteenth annual symposium on sea turtle biology and conservation: 217-217. Kalb, H.J. \& Wibbels, T. (Eds). Miami: US Dept. Commerce NOAA Technical Memorandum NMFS-SEFSC-443.

Carreras, C., Pascual, M., Cardona, L., Aguilar, A., Margaritoulis, D., Rees, A., Turkozan, O., Levy, Y., Gasith, A., Aureggi, M. \& Khalil, M. (2007). The genetic structure of the loggerhead sea turtle (Caretta caretta) in the Mediterranean as revealed by nuclear and mitochondrial DNA and its conservation implications. Conserv. Gen. 8, 761-775.

Casale, P. \& Margaritoulis, D. (2010). Sea turtles in the Mediterranean: distribution, threats and conservation priorities. Gland: IUCN.

Catry, P., Barbosa, C., Paris, B., Indjai, B., Almeida, A., Limoges, B., Silva, C. \& Pereira, H. (2009). Status, ecology, and conservation of sea turtles in GuineaBissau. Chelon. Conserv. Biol. 8, 150-160.

Cozens, J., Pereira, M., Mendes, E. \& Miles, R. (2009). First ever population census of nesting loggerheads on Sal island, Cabo Verde. In 29th annual symposium on sea turtle biology and conservation: 15. Limpus, C. (Ed.). Brisbane: ISTS.

Dodd, M. \& Mackinnon, A. (2005). Loggerhead turtle nesting in Georgia, 2005. Brunswick: Georgia Department of Natural Resources.

Eckert, K.L., Bjorndal, K.A., Abreu-Grobois, F.A. \& Donnelly, M. (1999). Research and management techniques for the conservation of sea turtles. IUCN/SSC Marine Turtle Specialist Group Publication No. 4.

Ehrhart, L.M., Bagley, D.A. \& Redfoot, W.E. (2003). Loggerhead turtles in the Atlantic Ocean: geographic distribution, abundance, and population status. In Loggerhead sea turtles: 157-174. Bolten, A.B. \& Witherington, B.E. (Eds). Washington, DC: Smithsonian Institution.

Encalada, S.E., Bjorndal, K.A., Bolten, A.B., Zurita, J.C., Schroeder, B., Possardt, E., Sears, C.J. \& Bowen, B.W. (1998). Population structure of loggerhead turtle (Caretta caretta) nesting colonies in the Atlantic and Mediterranean as inferred from mitochondrial DNA control region sequences. Mar. Biol. 130, 567-575.

Espírito-Santo, I., Martins, S., Simba, S., Marco, A., Abella, E., Sanz, P., da Graça, J. \& López-Jurado, L.F.
(2008). Efforts to increase the participation of local communities on the conservation of the endangered loggerhead population of Cape Verde. 28th Sea Turtle Symposium, Loreto, Baja California Sur, Mexico: ISTS.

FFC México AC (2006). Flora, Fauna y Cultura de México. Reporte del Programa de Protección y Conservación de Tortugas Marinas en el Litoral Central del Estado de Quintana Roo. Temporada 2005.

Florida Fish and Wildlife Conservation Commission, Fish and Wildlife Research Institute, Marine Turtle Program (2011). Loggerhead nesting in Florida. Available at: http://myfwc.com/research/wildlife/sea-turtles/nesting/ beach-survey-totals/ (accessed 10 January 2012).

Foote, A.D., Simila, T., Vikingsson, G.A. \& Stevick, P.T. (2010). Movement, site fidelity and connectivity in a top marine predator, the killer whale. Evol. Ecol. 24, 803814.

Forney, K.A. (2000). Environmental models of cetacean abundance: reducing uncertainty in population trends. Conserv. Biol. 14, 1271-1286.

Fretey, J. (2001). Biogeography and conservation of marine turtles of the Atlantic Coast of Africa/Biogéographie et conservation des tortues marines de la côte Atlantique de l'Afrique. CMS Technical Series Publication No. 6. Bonn, Germany: UNEP/CMS Secretariat.

Godfrey, M. \& North Carolina Wildlife Resources Commission (2007). Loggerhead nesting in North Carolina: personal communication. SWOT Report - State of the World's Sea Turtles, 2: 46.

Godley, B.J., Blumenthal, J.M., Broderick, A.C., Coyne, M.S., Godfrey, M.H., Hawkes, L.A. \& Witt, M.J. (2008). Satellite tracking of sea turtles: where have we been and where do we go next? Endang. Spec. Res. 4, 3-22.

Godley, B.J., Broderick, A.C. \& Hays, G.C. (2001). Nesting of green turtles (Chelonia mydas) at Ascension Island, South Atlantic. Biol. Conserv. 97, 151-158.

Godley, B.J. \& Wilson, R.P. (2008). Tracking vertebrates for conservation: introduction. Endang. Spec. Res. 4, 1-2.

Griffin, D. \& South Carolina Department of Natural Resources (2007). Loggerhead nesting in South Carolina. SWOT Report - State of the World's Sea Turtles, 2.

Halpin, P.N., Read, A.J., Best, B.D., Hyrenbach, K.D., Fujioka, E., Coyne, M.S., Crowder, L.B., Freeman, S.A. \& Spoerri, C. (2006). OBIS-SEAMAP: developing a biogeographic research data commons for the ecological studies of marine mammals, seabirds, and sea turtles. Mar. Ecol. Prog. Ser. 316, 239-246.

Hammond, P.S. (2010). Estimating the abundance of marine mammals. In Marine mammal ecology and conservation: a handbook of techniques: 42-67. Boyd, I.L., Bowen, W.D. \& Iverson, S. (Eds). Oxford: Oxford University Press.

IUCN (2011). Red list of threatened species. Available at: http://www.iucnredlist.org (accessed 10 January 2012). 
Kamezaki, N., Matsuzawa, Y., Abe, O., Asakawa, H., Fujii, T., Goto, K., Hagino, S., Hayami, M., Ishii, M., Iwamoto, T., Kamata, T., Kato, H., Kodama, J., Kondo, Y., Miyawaki, I., Mizobuchi, K., Nakamura, Y., Nakashima, Y., Naruse, H., Omuta, K., Samejima, M., Suganuma, H., Takeshita, H., Tanaka, T., Toji, T., Uematsu, M., Yamamoto, A., Yamato, T. \& Wakabayashi, I. (2003). Loggerhead turtles nesting in Japan. In Loggerhead sea turtles: 210-217. Bolten, A.B. \& Witherington, B.E. (Eds). Washington: Smithsonian Books.

López-Jurado, L.F. (2007). Historical review of the archipelagos of Macaronesia and the marine turtles. In Marine turtles - recovery of extinct populations: 53-76. López-Jurado, L.F. \& Liria-Loza, A. (Eds). Las Palmas de Gran Canaria: Instituto Canario de Ciencias Marinas.

López-Jurado, L.F., Cabrera, I., Cejudo, D., Evora, C. \& Alfama, P. (2000a). Distribution of marine turtles in the Archipelago of Cape Verde, Western Africa. In: Proceedings of the Nineteenth Annual Symposium on Sea Turtle Biology and Conservation. NOAA Technical Memorandum NMFS-SEFSC-443.

López-Jurado, L.F., Évora, C., Cabrera, I., Cejudo, D. \& Alfama, P. (2000b). Proposals for the conservation of marine turtles on the Island of Boa Vista (Republic of Cabo Verde, Western Africa). In: Proceedings of the 19th Annual Symposium on Sea Turtle Conservation and Biology. Kalb, H.J., Wibbels, T. (eds). South Padre Island, Texas. NOAA Technical Memorandum NMFSSEFSC-443.

López-Jurado, L.F., Sanz, P. \& Abella, E. (2007). Loggerhead nesting on Boa Vista, República de Cabo Verde. SWOT Report - State of the World's Sea Turtles, 2.

López-Jurado, L.F., Varo-Cruz, N. \& López-Suárez, P. (2003). Incidental capture of loggerhead turtles (Caretta caretta) on Boa Vista (Cape Verde Islands). Mar. Turtl. Newsl. 101, 14-16.

Loureiro, N.S. (2008). Sea turtles in Santiago Island, Cape Verde. Mar. Turtl. Newsl. 120, 6-8.

Loureiro, N.S. \& Ferraz-Torrao, M.M. (2008). Homens e tartarugas marinhas. Seis séculos de história e histórias nas ilhas de Cabo Verde. Anais Hist. Além-Mar. IX, 37-78.

Marcovaldi, M.A., Santos, A., Thomé, J.C., Soares, L., Barata, P. \& Projeto TAMAR-IBAMA (2007). Loggerhead nesting in Brazil. SWOT Report - State of the World's Sea Turtles, 2.

Margaritoulis, D., Argano, R., Baran, I., Bentivegna, F., Bradai, M.N., Camiñas, J.A., Casale, P., de Metrio, G., Demetropoulos, A., Gerosa, G., Godley, B.J., Haddoud, D.A., Houghton, J., Laurent, L. \& Lazar, B. (2003). Loggerhead turtles in the Mediterranean Sea: present knowledge and conservation perspectives. In Loggerhead sea turtles: 175-198. Bolten, A.B. \& Witherington, B.E. (Eds). Washington, DC: Smithsonian Institution Press.
Mau, R., Bedford, S., Richards, A. \& Ningaloo Turtle Program (2007). Loggerhead nesting in Western Australia: personal communication. SWOT Report - State of the World's Sea, 2.

Monzón-Argüello, C., López-Jurado, L.F., Rico, C., Marco, A., López, P., Hays, G. \& Lee, P.L.M. (2010a). Evidence from genetic and Lagrangian drifter data for transatlantic transport of small juvenile green turtles. $J$. Biog. 37, 1752-1766.

Monzón-Argüello, C., Rico, C., Carreras, C., Calabuig, P., Marco, A. \& López-Jurado, L.F. (2009). Variation in spatial distribution of juvenile loggerhead turtles in the Eastern Atlantic and Western Mediterranean sea. J. Exp. Mar. Biol. Ecol. 373, 79-86.

Monzón-Argüello, C., Rico, C., Marco, A., López, P. \& López-Jurado, L.F. (2010b). Genetic characterization of eastern Atlantic hawksbill turtles at a foraging group indicates major undiscovered nesting populations in the region. J. Exp. Mar. Biol. Ecol. 387, 9-14.

Monzón-Argüello, C., Rico, C., Naro-Maciel, E., VaroCruz, N., López, P., Marco, A. \& López-Jurado, L.F. (2010c). Population structure and conservation implications for the loggerhead sea turtle of the Cape Verde Islands. Conserv. Gen. 11, 1871-1884.

Nel, R., Wright, R. \& KwaZulu-Natal, E. (2007). Loggerhead nesting in South Africa. In: SWOT Report - State of the World's Sea Turtles, 2.

Poncet, S., Robertson, G., Phillips, R.A., Lawton, K., Phalan, B., Trathan, P.N. \& Croxall, J.P. (2006). Status and distribution of wandering, black-browed and greyheaded albatrosses breeding at South Georgia. Pol. Biol. 29, 772-781.

Ramos, R., González-Solís, J., Croxall, J.P., Oro, D. \& Ruiz, X. (2009). Understanding oceanic migrations with intrinsic biogeochemical markers. PLoS ONE 4, e6236.

Reis, E.C., Soares, L.S., Vargas, S.M., Santos, F.R., Young, R.J., Bjorndal, K.A., Bolten, A.B. \& Lobo- Hajdu, G. (2010). Genetic composition, population struc- ture and phylogeography of the loggerhead sea turtle: colonization hypothesis for the Brazilian rookeries. Conserv. Gen. 11, 1467-1477.

Robertson, D.R. (2008). Global biogeographical databases on marine fishes: caveat emptor. Divers. Distrib. 14, 891892.

Schleich, H.H. (1979). Sea turtle protection needed at the Cape Verde Islands. Mar. Turtl. Newsl. 12, 12.

Schroeder, B. \& Murphy, S. (1999). Population surveys (ground and aerial) on nesting beaches. Techniques for measuring sea turtles. In Research and management techniques for the conservation of sea turtles: 45-55. Eckert, K.L., Bjorndal, K.A., Abreu-Grobois, F.A. \& Donnelly, M. (Eds). Washington, DC: IUCN/SSC Marine Turtle Specialist Group Publication.

Stevick, P.T., Allen, J., Clapham, P.J., Katona, S.K., Larsen, F., Lien, J., Mattila, D.K., Palsboll, P.J., Sears, 
R., Sigurjonsson, J., Smith, T.D., Vikingsson, G., Oien, N. \& Hammond, P.S. (2006). Population spatial structuring on the feeding grounds in North Atlantic humpback whales (Megaptera novaeangliae). J. Zool. 270, 244-255.

Taylor, B.L., Martínez, M., Gerrodette, T., Barlow, J. \& Hrovat, Y.N. (2007). Lessons from monitoring trends in abundance or marine mammals. Mar. Mamm. Sci. 23, 157-175.

Tomas, J., Godley, B.J., Castroviejo, J. \& Raga, J.A. (2010). Bioko: critically important nesting habitat for sea turtles of West Africa. Biodivers. Conserv. 19, 2699-2714.

Varo-Cruz, N. (2010). Biología reproductora de la Tortug Boba (Caretta caretta Linneo, 1758) en la isla de BoaVista, archipiélago de Cabo Verde. PhD thesis, University of Las Palmas de Gran Canaria.

Varo-Cruz, N., Cejudo, D. \& López-Jurado, L.F. (2007). Reproductive biology of the loggerhead turtle (Caretta caretta L. 1758) on the island of Boa Vista (Cape Verde, West Africa). In Marine turtles. Recovery of extinct populations: 127-144. López-Jurado, L.F. \& Liria, A. (Eds). Las Palmas: Instituto Canario de Ciencias Marinas.
Wallace, B.P., DiMatteo, A.D., Hurley, B.J., Finkbeiner, E.M., Bolten, A.B., Chaloupka, M.Y., Hutchinson, B.J., Abreu-Grobois, F.A., Amorocho, D., Bjorndal, K.A., Bourjea, J., Bowen, B.W., Briseño-Dueñas, R., Casale, P., Choudhury, B.C., Costa, A., Dutton, P.H., Fallabrino, A., Girard, A., Girondot, M., Godfrey, M.H., Hamann, M., López-Mendilaharsu, M., Marcovaldi, M.A., Mortimer, J.A., Musick, J.A., Nel, R., Pilcher, N.J., Seminoff, J.A., Troëng, S., Witherington, B. \& Mast, R.B. (2010). Regional management units for marine turtles: a novel framework for prioritizing conservation and research across multiple scales. PLoS ONE 5, e15465.

Weir, C.R., Ron, T., Morais, M. \& Duarte, A.D.C. (2007). Nesting and at-sea distribution of marine turtles in Angola, West Africa, 2000-2006: occurrence, threats and conservation implications. Oryx 41, 224-231.

Witherington, B., Kubilis, P., Brost, B. \& Meylan, A. (2009). Decreasing annual nest counts in a globally important loggerhead sea turtle population. Ecol. Appl. 19, 30-54. 